\title{
1 Nanolimes doped with Quantum Dots for stone consolidation \\ 2 assessment
}

3 Javier Becerra ${ }^{1}$, Pilar Ortiz ${ }^{1}$, José María Martín ${ }^{1}$, Ana Paula Zaderenko ${ }^{1}$

4

$5 \quad{ }^{1}$ Departamento de Sistemas Físicos, Químicos y Naturales, Universidad Pablo de Olavide, Ctra.

6 Utrera Km1, ES-41013, Seville, Spain.

7

$8 \quad{ }^{*}$ Corresponding author: J. Becerra: jbeclun@upo.es

9

10 Abstract

11 Currently, the application of consolidation treatments based on nanolimes $\left(\mathrm{Ca}(\mathrm{OH})_{2}\right.$ nanoparticles) has become a common practice during the restoration of historical buildings. However, recent studies have showed that their effectiveness on stone materials is lower than expected. This result is due to the accumulation of nanolimes near the surface, which decreases their depth penetration into stone matrix and, consequently, results in a low restoration effectiveness.

17 This research is focused in a new nanocomposite based on $\mathrm{Ca}(\mathrm{OH})_{2}$ nanoparticles decorated with $\mathrm{ZnO}$ quantum dots whose fluorescence shows the real penetration of the nanomaterial into the stone matrices and allows us to study the affinity between nanolimes and the solvent used in the application in order to improve the penetration of the treatment in stones. Different mixtures of solvents have been probed to improve the surface depth penetration by analysing their kinetic stabilities and using thin-layer chromatography to evaluate their capacity to transport the nanolimes. Furthermore, a new support for thin-layer chromatography based on mortar has been 
24 designed, which has the advantage of having the same chemical composition as the limestones.

25 Moreover, the effectiveness of the treatments was studied on limestones from Puerto de Santa

26 María and Espera (Spain), which have been widely used in historical and contemporary

27 buildings in the southwest of Spain.

28 Nanolimes doped with $\mathrm{ZnO}$ quantum dots allow one to choose the optimal solvents for each 29 kind of stone based on their fluorescence from UV radiation. Additionally, the fluorescence of 30 the quantum dots could be used as an indicator of the consolidated areas for cultural heritage 31 applications.

32 Keywords

33 Stone consolidation, nanolimes, depth penetration, $\mathrm{ZnO}$ quantum dots 
One of the most common decays on historical stone buildings is the loss of cohesion of the stone matrices due to powdering, sanding, scaling or alveolation processes, all of which decrease the buildings' mechanical strength and diminish their original shapes. For that reason, restorers usually apply consolidation treatments during the restoration or intervention of monuments to try to recover the cohesion of the deteriorated stones. These treatments must satisfy several general requirements: compatibility with the original materials and effectiveness in improving the mechanical strength and durability [1,2]. However, the current consolidation treatments often lack of some of these requirements. For example, in the case of limestones, polymeric consolidants such as epoxy resins or acrylics normally are incompatible with the stone substrate (leading to strong alteration of stone porous systems, yellowing, biodeterioration, etc.) [3-6]. Silica-based consolidants, such as the widely used tetraethyl orthosilicate (TEOS) or ethyl silicate, have a low compatibility and durability despite their high penetration through the porous systems of the stone $[7,8]$. Finally, inorganic consolidants, such as limewater, are highly compatible with the original material and have good durability, although they have poor penetration and low effectiveness $[5,6,9,10]$.

New formulations from the nanotechnological field have enabled improving the properties of traditional inorganic consolidants. Nanolimes are colloidal dispersions of calcium hydroxide nanoparticles, which have the advantages of limewater (compatibility and durability) and a smaller size (between 50-600 nm), which enhance the penetration through the stones' porous systems $[11,12]$. The effectiveness of nanolimes as a consolidation treatment has been probed in some monuments, thus achieving a good pre-consolidation over different materials, especially mural paintings and stones [6,7,13-15]. Nevertheless, this treatment often shows a poor effectiveness when mass consolidation is required since it generates a white haze on the surface $[8,16-18]$. According to recent studies $[1,8]$, this phenomenon is due to the back migration of the nanoparticles to the surface during the evaporation of the solvent. This approach suggests 
through the decayed stone. Borsoi et al. [19] proposes a relation between stones' porous sizes and the kinetic stability of the dispersion to favour the precipitation of the nanoparticles at the end of the absorption process, thus preventing their back migration to the surface.

In this research, we have clarified the behaviours of the colloidal dispersion of nanolimes by studying the kinetic stability of different solvents. The affinity of the nanoparticles to the solvent or the substrate was studied using a chromatography assay and using two different substrate materials based on silica or lime. Furthermore, a selection of the different colloids that were studied was probed in limestone from Puerto de Santa María and Espera (Spain), which present substantial differences in their physical properties. These limestones were widely used in historical building, such as the important town hall [20] and the cathedral [21] of Seville (Spain) and are employed currently as construction materials.

With this objective, the nanolimes were decorated with zinc oxide quantum dots ( $\mathrm{ZnO}$ QDs). QDs have a high luminescent efficiency [22] and have a wide variety of applications, such as in nanosensors, cosmetic products, nano-electronics, nano-optical devices and energy storage [23,24]. Moreover, $\mathrm{ZnO}$ QDs are stable, nontoxic and low cost $[23,25]$, and these and other characteristics allow us to choose them as building treatments to evaluate the real depth penetration of the nanolime treatment.

\section{Materials and Methods}

\subsection{Synthesis of $\mathrm{CaOH}_{2}$ nanoparticles decorated with $\mathrm{ZnO}$ quantum dots}

Zinc acetate $\left(\mathrm{Z}_{\mathrm{n}} \mathrm{C}_{4} \mathrm{H}_{6} \mathrm{O}_{4}\right)$, potassium hydroxide $(\mathrm{KOH})$ and (3-aminopropyl)trimethoxysilane (APTES) were purchased from Sigma-Aldrich, tetraethylorthosilicate (TEOS) from Acros and calcium hydroxide nanoparticles $\left(\mathrm{Ca}(\mathrm{OH})_{2}\right.$ Nanorestore $\left.{ }^{\circledR}\right)$ from CTS. All other chemicals were reagent grade. Water was purified using a Milli-Q reagent grade water system from Millipore.

$\mathrm{ZnO}$ quantum dots were synthesized according to the method described by Patra et al. [25] with some modifications. Briefly, a methanol solution of $\mathrm{KOH}(10 \mathrm{~mL}, 2.5 \mathrm{M})$ was added to a 
methanol solution of zinc acetate $(25 \mathrm{~mL}, 0.1 \mathrm{M})$ under magnetic stirring. Immediately after, 25 $\mathrm{mL}$ of Nanorestore ${ }^{\circledR}$ (isopropanol solution of $\mathrm{Ca}(\mathrm{OH})_{2}$ nanoparticles at the concentration of 5 $\mathrm{g} / \mathrm{L}$ ) was added, and the resulting colloid was magnetically stirred for $1 \mathrm{~h}$. The formation of $\mathrm{ZnO}$ quantum dots shows bright yellow-green luminescence under UV excitation. At this point, $250 \mu \mathrm{L}$ of TEOS solution and $500 \mu \mathrm{L}$ of water were added to control the quantum dot growth. After the reaction, the pellets with the nanolimes decorated with $\mathrm{ZnO}$ quantum dots were recovered by centrifugation (5000 rpm, $10 \mathrm{~min}$ ), which made resuspending the pellets in an isopropanol solution easy. The isopropanol dispersion of colloids was stored in the dark until being applied over stone samples.

One modification was carried out by adding $250 \mu \mathrm{L}$ of APTES instead of TEOS in the synthesis process. Thereby, two different nanolimes decorated with $\mathrm{ZnO}$ quantum dots were synthesized and named according to the stabilized products: $\mathrm{Ca}(\mathrm{OH})_{2} / \mathrm{ZnO} @$ TEOS and $\mathrm{Ca}(\mathrm{OH})_{2} / \mathrm{ZnO} @$ APTES.

The nanocomposites were characterized by scanning electron microscope equipped with energydispersive X-ray spectroscopy (SEM-EDS) and fluorescence spectroscopy. SEM images were recorded with a GeminiSEM 300 microscope, and EDS was carried out with an Oxford Instruments Detector EDS X-Max 50. The fluorescence spectra were recorded using an Ocean Optics USB2000 + fluorimeter, a $100 \mathrm{~W}$ xenon arc with an arc lamp power supply model LSN152, and a lamp housing model LSH102, which were all provided by Lot Oriel.

\subsection{Kinetic stability assay}

The kinetic stability of the nanolimes is a decisive factor for understanding their precipitation process during their depth penetration in limestones, according to research carried out by Borsoi et al. [26]. For that study, $\mathrm{Ca}(\mathrm{OH})_{2}$ nanoparticles and $\mathrm{Ca}(\mathrm{OH})_{2}$ nanoparticles decorated with ZnO DQs were studied as the first step to understanding their behaviours on the limestone substrates. The solvents used in the kinetic stability assay were water, ethanol, isopropanol, octanol, dimethyl sulfoxide, dimethylformamide, acetone, ethyl acetate, dipentene, toluene and 
113 hexane (ordered from highest to lowest polarity), and their main characteristics are illustrated in

114 Table 1.

115 Table 1. Physical-chemical properties of the selected solvents [27-30]

\begin{tabular}{|c|c|c|c|c|c|c|c|c|}
\hline Solvent & $\begin{array}{l}\text { Viscosity } \\
\text { at } 25^{\circ} \mathrm{C} \\
\text { (mPas) }\end{array}$ & $\begin{array}{c}\text { Surface } \\
\text { tension at } \\
20^{\circ} \mathrm{C} \\
\left(\mathrm{m} N \mathrm{~m}^{-1}\right)\end{array}$ & $\begin{array}{c}\text { Boiling } \\
\text { point } \\
\left({ }^{\circ} \mathrm{C}\right)\end{array}$ & $\begin{array}{c}\text { Vapour } \\
\text { pressure at } \\
25^{\circ} \mathrm{C}(\mathrm{kPa})\end{array}$ & $\begin{array}{c}\text { Evaporation } \\
\text { rate (butyl } \\
\text { acetate }=1)\end{array}$ & $\begin{array}{c}\text { Relative } \\
\text { permitti- } \\
\text { vity }\end{array}$ & $\begin{array}{c}\text { Polarity } \\
\text { parameter, } \\
\text { ET }_{T}(30) \\
\left(\mathrm{Kcal} \mathrm{mol}^{-1}\right)\end{array}$ & $\begin{array}{c}T W A 8 h, \\
\text { NIOSH* } \\
\text { (ppm) }\end{array}$ \\
\hline Water & 0.8949 & 71.97 & 99.61 & - & - & 80.4 & 63.1 & - \\
\hline Ethanol & 1.263 & 21.99 & 78.4 & 5.9466 & 2.0 & 24.30 & 51.9 & 1000 \\
\hline Isopropanol & 2.1 & 21.40 & 82.2 & 4.1 & 2.90 & 18.60 & 48.6 & 400 \\
\hline Octanol & 7.363 & 26.92 & 204.0 & 0.009 & 0.01 & 10.34 & 48.3 & - \\
\hline $\begin{array}{l}\text { Dimethyl } \\
\text { sulfoxide }\end{array}$ & 1.991 & 42.98 & 189.0 & 0.08166 & 0.03 & 46.45 & 45.0 & - \\
\hline $\begin{array}{l}\text { Dimethylfor } \\
\text { mamide }\end{array}$ & 0.802 & 37.9 & 153.0 & 0.492 & 3.7 & - & 43.8 & 10 \\
\hline Acetone & 0.3029 & 22.68 & 56.1 & 30.8 & 6.60 & 20.56 & 42.2 & 250 \\
\hline Ethyl acetate & 0.426 & 23.75 & 77.1 & 11.46 & 4.10 & 6.02 & 38.1 & 400 \\
\hline Dipentene & 0.923 & 26.87 & 176.0 & 0.2667 & 0.20 & 2.38 & - & - \\
\hline Toluene & $\begin{array}{c}0.54 \\
\left(20^{\circ} \mathrm{C}\right)\end{array}$ & 29.6 & 110.6 & $20\left(18.4^{\circ} \mathrm{C}\right)$ & - & 2.4 & 33.9 & 200 \\
\hline Hexane & 0.294 & 17.94 & 68.7 & 20.17 & 6.82 & 1.88 & 30.9 & 50 \\
\hline
\end{tabular}

*The time-weighted average concentration for a conventional 8-hour workday and 40-hour workweek exposure to a substance, to which it is believed that nearly all workers may be repeatedly exposed, day after day, without adverse health effects. The data are given by National Institute for Occupational Safety and Health (NIOSH).

117 The kinetic stabilities of the colloids were determined by turbidity measurements. The 118 absorbance at $600 \mathrm{~nm}$ was considered as the parameter proportional to the turbidity of the 119 dispersion, and its value decreases over time due to particle agglomeration and settling. The measures were recorded by a UV-Vis spectrophotometer (Ocean Optics spectrometer equipped with a HR4000 detector) at different times $(0,0.5,1,1.5,3,24$ and $48 \mathrm{~h})$. The kinetic stability time was considered for the period until the total decantation of the dispersion, namely, until the absorbance values of its supernatant liquid were stable and continuous.

124 For this assay, the different nanoparticles were centrifuged at $5000 \mathrm{rpm}$ for 10 minutes and resuspended in each of the solvents. These colloids were diluted in the same solvent at the ratio of 1:5 and placed in $3 \mathrm{~mL}$ glass test tubes, which were capped to avoid the solvents'

127 evaporation. The colloids were sonicated at the beginning of the assay for 30 minutes to avoid nanoparticle aggregation. 
130 Chromatography in the liquid phase was carried out to analyse the affinity between the

131 nanoparticles and the different solvents in different substrates. Thin-layer chromatography

132 (TLC) was performed on aluminium plates that were pre-coated with silica gel (TLC-sheets

133 Alugram ${ }^{\circledR}$ Sil G $\left./ \mathrm{UV}_{245}\right)$. The size of the plates was $4.5 \times 1 \mathrm{~cm}$. Moreover, new chromatography 134 plates based on mortar were designed with the main objective to analyse this phenomenon in a 135 substrate more similar to limestone. To prepare those plates, microscope slides of $76 \times 26 \mathrm{~mm}$ 136 were sanded and scratched, and a thin layer of lime and sand mortar was extended along the 137 plate length. The mortars were dried at room temperature for few weeks.

138 Chromatography was performed via the capillarity of the colloidal dispersions. Briefly, the 139 initial suspensions of nanoparticles were centrifuged at $5000 \mathrm{rpm}$ for $10 \mathrm{~min}$ and then 140 resuspended in the following solvents (water, ethanol, isopropanol, acetone and dipentene) 141 according to the results of the kinetic stability assay. Additionally, these colloids were diluted in 142 the same solvent at the ratio of $1: 1$ in order to reach a final concentration of nanolimes of 2.5 $143 \mathrm{~g} / \mathrm{L}$. The dissolutions were stirred for $15 \mathrm{~min}$.

144 The distance travelled relative to the solvent $\left(\mathrm{R}_{\mathrm{f}}\right)$ was calculated according to equation 1.

\subsection{Treatment evaluation scheme}

147 Figure 1 shows a scheme of the methodology followed for the treatment evaluation of the 148 consolidates for historical buildings and archaeological stone materials. These schemes are 149 divided in two phases.

Phase 1: It is a preliminary trial to study the depth penetration and carbonation process of silicacoated $\mathrm{ZnO}$ QDs, which will allow us to choose the optimal QDs for the study.

Phase 2: It is an approach for the evaluation of treatments based on the nanolimes doped with the chosen QDs, enabling the evaluation of their applicability for cultural heritage and their effectiveness as consolidants for limestones. 


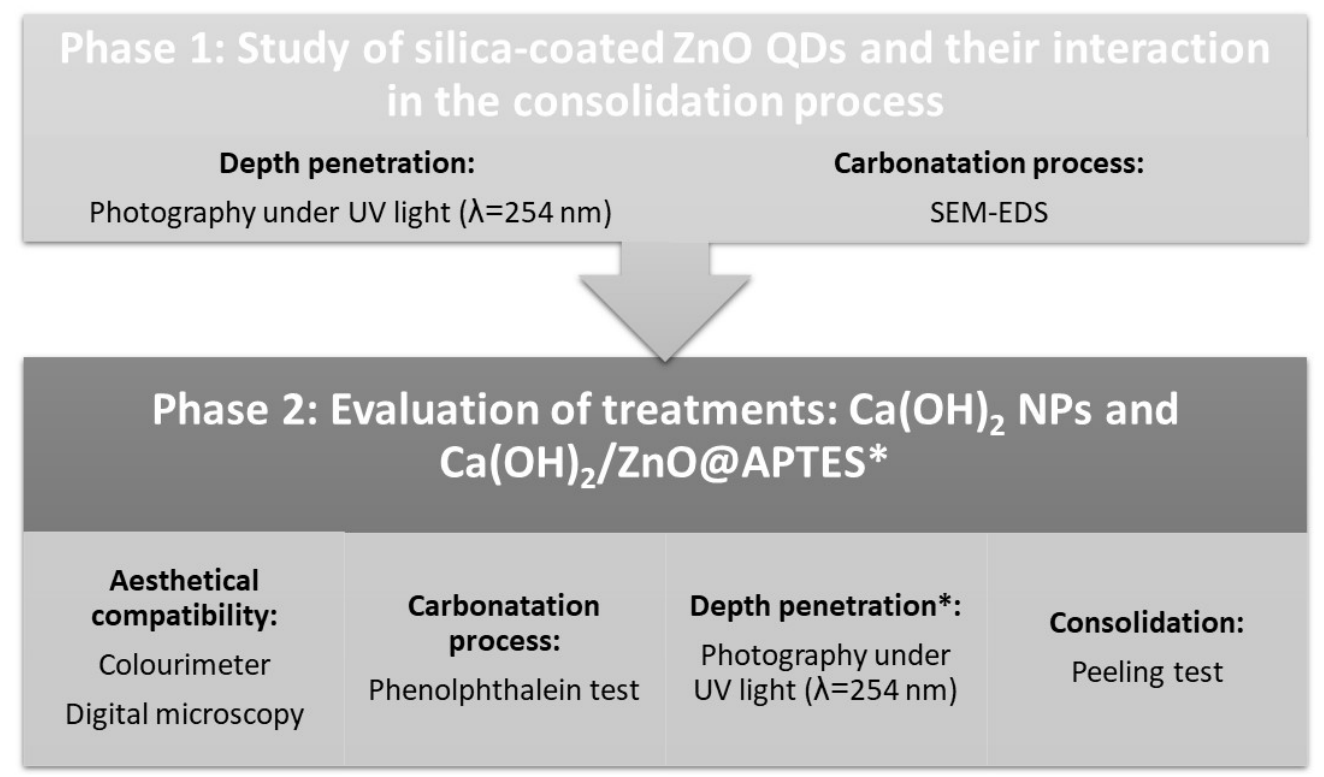

Fig. 1. Methodology of the evaluation of the treatments over stones.

\subsubsection{Selection of the silica-coated $\mathrm{ZnO}$ QDs}

The preliminary trial (phase 1 of Fig. 1) was designed to select the optimal silica-coated $\mathrm{ZnO}$ QDs and study their possible interference in the carbonatation process of nanolimes.

For this trial, limestone slabs $(2.5 \times 2.5 \times 1 \mathrm{~cm})$ from Puerto de Santa María were treated by $\mathrm{Ca}(\mathrm{OH})_{2} / \mathrm{ZnO} @ \mathrm{APTES}$ and $\mathrm{Ca}(\mathrm{OH})_{2} / \mathrm{ZnO} @$ TEOS at a concentration of $2.5 \mathrm{~g}$ nanolimes/L. The treatment was applied with a brush over the slab surfaces until it was apparently refused. $(\lambda=254 \mathrm{~nm})$. The evaluation of the nanolime carbonatation was based on the generation of calcium carbonate in the samples [31]. SEM images were recorded in a GeminiSEM 300 microscope. Additionally, the effectiveness of the ZnO QDs as a tracer was studied by EDS. The EDS spectra were recorded by an Oxford Instruments Detector EDS X-Max 50.

\subsubsection{Application on stone samples and evaluation of treatments}

Limestone slabs $(2.5 \times 2.5 \times 2.5 \mathrm{~cm})$ were employed to analyse the penetration and consolidation properties of nanolimes (phase 2 of Fig. 1). For the trials, limestone slabs from the quarries of Puerto de Santa María and Espera (Cádiz, Spain) were chosen. These quarries were 
used in the construction of important historical buildings in the south of Spain, such as the Cathedral [21] or the Town Hall [20] of Seville.

The limestone from Puerto de Santa Maria (PSM) is a white-yellow biosparitic calcarenite, which has a powdery appearance on the monument surfaces. This stone is made up predominantly of carbonated and silica grains and a cement of calcite. The pore diameter of the stone is between 10 and $100 \mu \mathrm{m}$ according to Guerrero [20]. The limestone from Espera (ESP) is a yellow biosparitic limestone with a homogeneous chemical composition based on calcite and quartz. The stone has a pore diameter between 10 and $75 \mu \mathrm{m}$ [20]. The open porosity of the PSM and ESP stones was calculated according to UNE-EN 13755 [32] as 14.3\% and 5.9\%, respectively. Additionally, their water absorption coefficient by the capillarity was also calculated according to UNE-EN 1925 [33] as 179.3 and $38.6 \mathrm{~g} / \mathrm{m}^{2} . \mathrm{s}^{0.5}$, respectively.

$\mathrm{Ca}(\mathrm{OH})_{2}$ and $\mathrm{Ca}(\mathrm{OH})_{2} / \mathrm{ZnO} @$ APTES were applied at a nanolime concentration of $2.5 \mathrm{~g} / \mathrm{L}$ and resuspended in five different solvents: water, ethanol, isopropanol, acetone and dipentene. The quantity of the treatment was calculated using the criteria employed by Pinho and Mosquera [34] for stone consolidates, where the product is applied until the surface's apparent refusal of treatment. Consequently, the requirement of consolidation treatment was different between both limestones, which was evident by their open porosity and absorption capacity, being $1.9 \mathrm{~mL}$ for PSM slabs and $1 \mathrm{~mL}$ for ESP slabs. Four applications were carried out over each slab by brushing on the treatment and allowing it to dry at room temperature $\left(24^{\circ} \pm 2\right)$ for 20 days after the last application. The assay was performed in triplicate.

The aesthetic compatibility was measured by colourimetry (colourimeter PCE-CSM 2, diameter of circular measuring area: $8 \mathrm{~mm}$, daylight illumination: D65). The chromatic variations $\left(\Delta \mathrm{E}^{*}\right)$ after treatments were calculated using the parameters defined by the CIELAB colour-system according to equation 2 .

$$
\Delta \mathrm{E}^{*}=\sqrt{\Delta \mathrm{L}^{* 2}+\Delta \mathrm{a}^{* 2}+\Delta \mathrm{b}^{* 2}}
$$

Eq. 2 
197 where $\Delta \mathrm{L}^{*}, \Delta \mathrm{a}^{*}$ and $\Delta \mathrm{b}^{*}$ characterize the variations in the colour values from the controls in the 198 black-white (brightness), red-green and yellow-blue axes, respectively. $\Delta \mathrm{L}^{*}, \Delta \mathrm{a}^{*}$ and $\Delta \mathrm{b}^{*}$ were 199 calculated as the variations between initial and final colour slabs.

200 After 20 days of drying, the limestone slabs were broken with a stone cutting machine into two 201 halves. On one side, the ending of the carbonatation process was checked by a phenolphthalein 202 test, and on the other side, the surface depth penetration of the treatments doped with ZnO QDs was observed under UV light. Additionally, the drying surface and cross-section samples were studied by a Zarbeco MiScope MP2 handheld digital microscope with 40 - 140X magnification lens.

The total carbonatation of the treatment was evaluated by the phenolphthalein test according to Borsoi et al. [35]. A solution of $1 \%$ phenolphthalein $(60 \%$ ethanol- $40 \%$ water) was nebulized over the cross-section of the samples after 20 days of the application of the treatments. Phenolphthalein is a common $\mathrm{pH}$ indicator that remains uncoloured for $\mathrm{pH}<8$.2. In $\mathrm{pH}>9.8$, the indicator colour changes to a purple colour. In this case, the presence of $\mathrm{Ca}(\mathrm{OH})_{2}$ increases the $\mathrm{pH}$ beyond 11 and leads to the purple colour of the substrate. Nevertheless, the formation of the $\mathrm{CaCO}_{3}$ remains uncoloured in the substrate due to it being a neutral compound.

The actual penetration of the $\mathrm{Ca}(\mathrm{OH})_{2} / \mathrm{ZnO} @$ APTES treatments was observed in the crosssectional samples with a UV lamp at $254 \mathrm{~nm}$. The measurements were taken with an image processing program (ImageJ).

216 The consolidation of treated limestones was studied by the peeling test. This assay was carried 217 out according to previously reported methods [36] using Scotch ${ }^{\circledR}$ Cristal tape (3 M) with 10 218 repetitions over the same location.

219 The percentage of consolidation (\% Consolidation) relative to that of untreated samples was 220 calculated according to equation 3. 
where $\mathrm{TRM}_{\text {untreated }}$ is the total removed material in the untreated sample and $\mathrm{TRM}_{\text {treated }}$ is the total removed material in the treated sample.

\section{Results and Discussion}

\subsection{Synthesis and characterization}

The consolidation treatment based on nanolimes was selected to evaluate its penetration into the stone matrix. For that process, the $\mathrm{Ca}(\mathrm{OH})_{2}$ nanoparticles were decorated with $\mathrm{ZnO}$ QDs, which have fluorescence in the UV wavelength. The nanocomposites that were synthesized form a white colloid that can be recovered easily by centrifugation (5000 rpm, $10 \mathrm{~min})$ and resuspended in different solvents. In this case, the pellet was resuspended in isopropanol at the initial concentration of the commercial product ( $5 \mathrm{~g}$ nanolimes $/ \mathrm{L})$ for the nanoparticle conservation.

The $\mathrm{Ca}(\mathrm{OH})_{2}$ nanoparticles of Nanorestore are hexagonal portlandite platelets with an average size of less than $100 \mathrm{~nm}$, as determined by TEM [37,38]. Additionally, the ZnO QDs are spherical particles with an average size estimated at $7.7 \pm 1.4 \mathrm{~nm}$ by electron microscopy, which is consistent with the size of $8 \mathrm{~nm}$ described by Patra et al. [25]. Fig. 2A shows the hexagonal $\mathrm{Ca}(\mathrm{OH})_{2}$ nanoparticle platelets according the description of Daniele et al. [9], which are decorated by tiny ZnO QDs with spheres shapes that were previously described by Patra et al. [25] and are distributed heterogeneously. The presence of Zn was corroborated by EDS (Fig. 2B) and also appeared in the peaks of the Si used in the stabilization process of the QD growth. After two days of drying, the rhombohedral crystals of calcite were observed with a medium size of $0.5-1 \mu \mathrm{m}$ (Fig. 2C). This mineral is the most stable and least soluble calcium carbonate [31]. The calcium and zinc maps show that the $\mathrm{ZnO}$ QDs remain around the new crystals of calcite (Fig. 2D-E) and do not prevent the carbonatation process. 

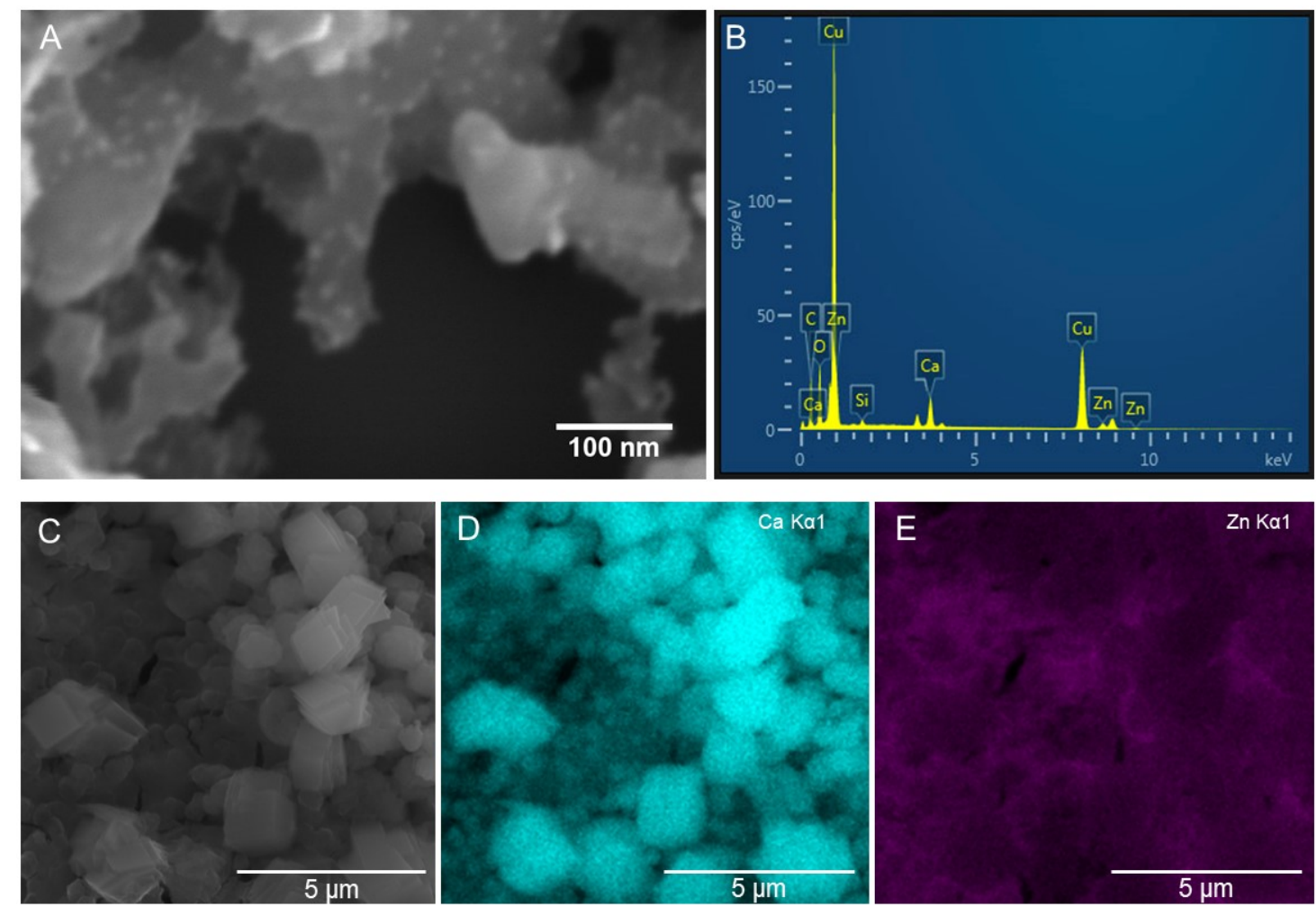

247 Fig. 2. SEM images of the $\mathrm{Ca}(\mathrm{OH})_{2}$ nanoparticles decorated with $\mathrm{ZnO}$ QDs posed over a copper

248 grid (A) and EDS spectra (B). The SEM image of $\mathrm{Ca}(\mathrm{OH})_{2}$ nanoparticles decorated with $\mathrm{ZnO}$

249 QDs after one day of drying (C) and the EDS mapping of calcium and zinc (D and E, 250 respectively) of that image.

251 Finally, the fluorescence of the ZnO QDs was studied in methanol. It has been reported that the 252 broad emission from $\mathrm{ZnO}$ in the visible region is a spectrum of multiple emission bands 253 originating from a variety of vacancies and interstitial defects on the surface and grain 254 boundaries of $\mathrm{ZnO}[25,39]$. Fig. 3 shows a broad emission spectrum that highlights the peaks at 255483 and $525 \mathrm{~nm}$ that correspond to the blue and green regions, respectively. Patra et al. [25] 256 suggest that the main peak in the green region could fluctuate between 510 and $534 \mathrm{~nm}$ as a 257 function of the size of the QDs. The inset image in Fig. 3 shows the white-yellow fluorescence of the QDs under a UV light $(\lambda=254 \mathrm{~nm})$. 


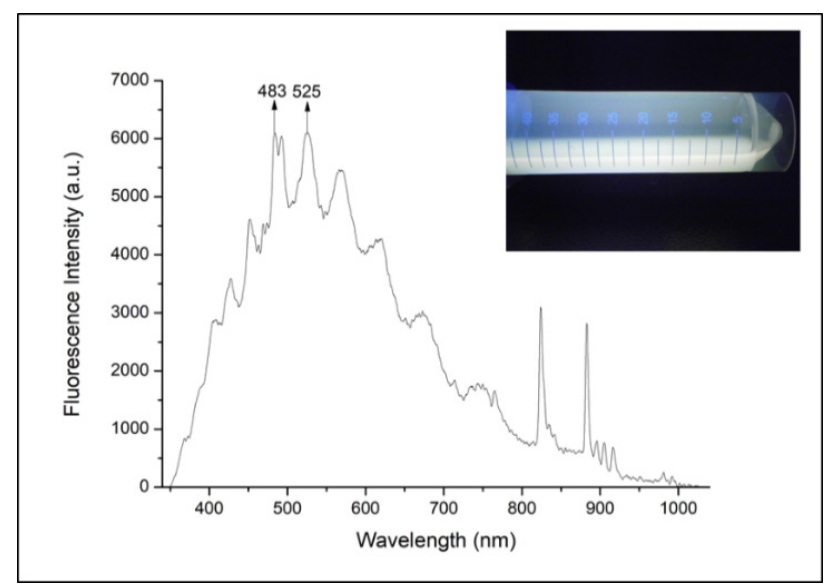

Fig. 3. Fluorescence emission spectra of $\mathrm{ZnO}$ QDs at the excitation wavelength from 250 to 900 $\mathrm{nm}$ by an arc of neon. The inset is an image of the fluorescence of the QDs at the wavelength of $254 \mathrm{~nm}$.

\subsection{Kinetic stability assay}

The kinetic stability of the $\mathrm{Ca}(\mathrm{OH})_{2}$ nanoparticles and $\mathrm{Ca}(\mathrm{OH})_{2}$ nanoparticles decorated with ZnO QDs dispersed in different solvents (Table 1) was evaluated by turbidity measurements compared with the decantation process under visible and UV lights. In this way, the kinetic stability time was established for each dispersion.

The $\mathrm{Ca}(\mathrm{OH})_{2}$ nanoparticles showed great stability in a wide range of the solvents (Table 2), especially in alcohols, dimethyl sulfoxide and dimethylformamide, for more than 48 hours. In contrast, these nanoparticles were very unstable in water, toluene and hexane, solvents that are classified as more polar (water) or non-polar (toluene, hexane) than the other solvents used.

272 Salvadori and Dei [37] show that the low stability of the nanolimes in water is due to the lower 273 effectiveness of the water as a peptizer. In fact, the absorption of solvent molecules onto the surfaces of nanolimes led to their subsequent stabilization [40].

275 The nanolimes doped with ZnO QDs had lower stability than did the non-doped nanolimes due 276 to the modification of the nanoparticle surface with the QDs. The use of different silica coatings 277 in the $\mathrm{ZnO}$ QDs showed remarkable differences between them. The use of (3aminopropyl)trimethoxysilane (APTES) provided a great stability to the nanoparticles in 
alcohols, dimethyl sulfoxide and dimethylformamide, while it decreased the stabilization in solvents with less polarity. The presence of tetraethylorthosilicate (TEOS) in the nanoparticles decreased their kinetic stability in all of the solvents except for octanol, in which the stability was above 48 hours. This different behaviour between these two silica-coatings could be due to the presence of amino groups on the surface of the ZnO@APTES QDs [41], while the presence only of methyl groups in the surface favoured a trend to agglomerate nanoparticles.

\begin{tabular}{|c|c|c|c|c|c|c|c|c|c|c|c|}
\hline \multirow[b]{2}{*}{ Nanoparticle } & \multicolumn{11}{|c|}{ Solvent } \\
\hline & 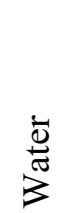 & $\begin{array}{l}\overline{0} \\
\text { 志 } \\
\text { 壱 }\end{array}$ & 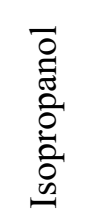 & $\begin{array}{l}\overline{0} \\
\text { त्ञ } \\
\text { O }\end{array}$ & 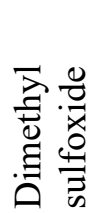 & 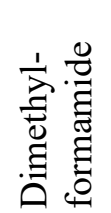 & $\frac{\mathscr{0}}{\stackrel{0}{0}}$ & 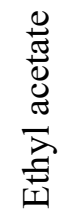 & 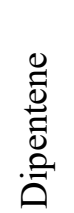 & $\frac{\stackrel{0}{0}}{\stackrel{0}{0}}$ & 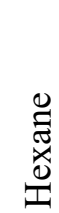 \\
\hline$\overline{\mathrm{Ca}(\mathrm{OH})_{2}}$ & 0 & $>48$ & $>48$ & $>48$ & $>48$ & $>48$ & 24 & 24 & 24 & 0 & 0 \\
\hline $\begin{array}{l}\mathrm{Ca}(\mathrm{OH})_{2} / \mathrm{ZnO} @ \mathrm{APTE} \\
\mathrm{S}\end{array}$ & 0.5 & $>48$ & $>48$ & 24 & $>48$ & $>48$ & 0.5 & 0 & 0.5 & 0 & 0 \\
\hline $\mathrm{Ca}(\mathrm{OH})_{2} / \mathrm{ZnO} @ \mathrm{TEOS}$ & 0 & 24 & 0.5 & $>48$ & 0.5 & 0.5 & 0 & 0.5 & 0.5 & 0 & 0.5 \\
\hline
\end{tabular}

In general, the higher stability was obtained with alcohols (ethanol, isopropanol and octanol), which is in agreement with other studies $[26,42,43]$. The kinetic stability decreased with the increase in the solvent non-polarity. The exception was water, the most polar solvent analysed, where nanoparticles were not stable either according to the results found by Rodriguez-Navarro et al. [15] and Licchelli et al. [44].

Taking into consideration these results, we made the selection of solvents for the next assay (section 3.3.) by choosing a range of solvents with different capacities to maintain the $\mathrm{Ca}(\mathrm{OH})_{2}$ nanoparticle stability. The chosen solvents were ethanol, isopropanol, dipentene, acetone and water, which are arranged from the highest to lowest kinetic stability of the solvent. the time-weighted average (TWA) given by the National Institute for Occupational Safety and Health (NIOSH). Therefore, the solvents could be used by restorers for building or 
(Table 1), except for acetone (250 ppm).

\subsection{Chromatography assays}

302

303

304

305

306

307

308

309

310

311

312

313

A chromatography assay was carried out on $\mathrm{Ca}(\mathrm{OH})_{2}$ decorated with $\mathrm{ZnO}$ QDs, and the measurement of the $\mathrm{R}_{\mathrm{f}}$ was easy thanks to the fluorescence of the ZnO QDs under UV radiation $(\lambda=254 \mathrm{~nm})$.

One of the most important objectives of this assay was corroborated by the influence of the substrate composition in the solvent and its capability to shift the nanoparticles on the substrate. Until now, all the studies were focused on the nanoparticle-solvent interaction [17,26,43-46]. Nevertheless, it is necessary take into consideration a third factor, which is the substrate where the nanoparticle will be applied. As could be seen in Table 3, the $\mathrm{R}_{\mathrm{f}}$ between silica gel (TLCsheets Alugram ${ }^{\circledR}$ Sil) and mortar chromatographic substrate is different. The best $R_{f}$ was achieved in mortar substrates with a composition similar to that of limestones. In fact, the presence of the silica-coating on the $\mathrm{ZnO}$ QDs made the resulting nanoparticles have a higher attraction to the silica gel substrate, which may be caused by the presence of methyl groups and the possibility to generate tight links with the substrate [47]. Thereby, the distance travelled by the nanoparticles decreased in comparison with that of the same product in the different chromatographic substrate (mortars), as seen in Table 3.

Table 3. Distance travelled relative to the solvent $\left(\mathrm{R}_{\mathrm{f}}\right)$ as obtained by chromatography assays.

$\mathrm{Ca}(\mathrm{OH})_{2} / \mathrm{ZnO} @$ APTES

\begin{tabular}{|c|c|c|c|c|c|c|c|c|c|c|}
\hline Solvent & $\begin{array}{l}\overrightarrow{\tilde{\omega}} \\
\stackrel{\omega}{*} \\
\overrightarrow{3}\end{array}$ & 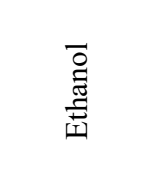 & $\begin{array}{l}\overline{0} \\
\overline{0} \\
\overline{0} \\
\overline{0} \\
\overline{0} \\
.0\end{array}$ & 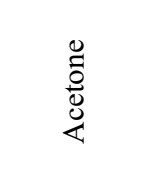 & 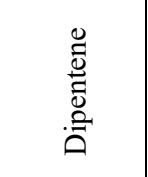 & $\begin{array}{l}\overrightarrow{\tilde{J}} \\
\stackrel{\omega}{3}\end{array}$ & 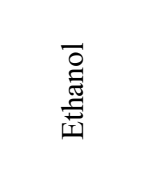 & 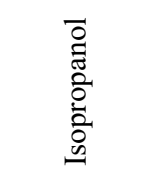 & $\begin{array}{l}0 \\
\frac{0}{0} \\
\frac{0}{0} \\
\end{array}$ & 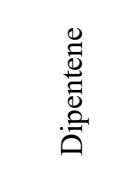 \\
\hline $\begin{array}{c}\begin{array}{c}\text { Silica gel } \\
\left(\text { Alugram }{ }^{\circledR}\right)\end{array} \\
\end{array}$ & $0.12 \pm 0.01$ & $0.11 \pm 0.01$ & $0.23 \pm 0.04$ & $0.10 \pm 0.01$ & $0.06 \pm 0.01$ & $0.13 \pm 0.01$ & $0.12 \pm 0.01$ & $0.10 \pm 0.01$ & $0.07 \pm 0.01$ & $0.32 \pm 0.01$ \\
\hline Mortar & $0.18 \pm 0.02$ & $0.24 \pm 0.02$ & $0.38 \pm 0.02$ & $0.10 \pm 0.01$ & $0.11 \pm 0.01$ & $0.23 \pm 0.03$ & $0.34 \pm 0.02$ & $0.19 \pm 0.05$ & $0.21 \pm 0.01$ & $0.40 \pm 0.04$ \\
\hline
\end{tabular}


319 In general, the $\mathrm{Ca}(\mathrm{OH})_{2} / \mathrm{ZnO} @$ TEOS nanoparticles showed higher $\mathrm{R}_{\mathrm{f}}$ values than did the

$320 \mathrm{Ca}(\mathrm{OH})_{2} / \mathrm{ZnO} @$ APTES nanoparticles.

321 In the case of the $\mathrm{Ca}(\mathrm{OH})_{2} / \mathrm{ZnO} @$ APTES nanoparticles, isopropanol suspensions displayed the

322 best $R_{f}$ in both the silica gel and mortar substrates, with $R_{f}$ values of 0.23 and 0.38 , respectively.

323 The great kinetic stability of this dispersion ( $>48$ hours) facilitates the chromatographic ascent

324 of the nanoparticles shifted by solvents. In agreement with that assessment, the solvents with

325 lower kinetic stability (water, acetone and dipentene) resulted in decreased $R_{f}$ values (Table 3 ).

326 Against what was expected, the best $\mathrm{R}_{\mathrm{f}}$ for $\mathrm{Ca}(\mathrm{OH})_{2} / \mathrm{ZnO} @$ TEOS was obtained with a low-

327 kinetic-stability solvent, dipentene (0.32 in silica gel and 0.4 in mortar substrate). Ethanol had a

328 good result, while isopropanol considerably decreased the capability of the treatment to shift the

329 nanoparticles compared to the results achieved by the $\mathrm{Ca}(\mathrm{OH})_{2} / \mathrm{ZnO} @$ APTES nanoparticles.

In summary, this new approach helps to understand the behaviour of the nanolime dissolution in different substrates. If the affinity between the nanoparticles and substrate is high, then the chromatographic progression decreases. A good selection of the solvent considerably improves the $\mathrm{R}_{\mathrm{f}}$ value, especially in the case of alcohols, which showed the highest kinetic stability.

\subsection{Treatment evaluation}

\subsubsection{Selection of silica-coated ZnO QDs}

Ethanol was used to carry out the selection of silica-coated $\mathrm{ZnO}$ QDs due to its great kinetic stability, which was $24 \mathrm{~h}$ for the TEOS-coated samples and more than $48 \mathrm{~h}$ for the APTEScoated samples, and its high $\mathrm{R}_{\mathrm{f}}$ for both nanolimes, 0.34 and 0.24 for the TEOS- and APTEScoated samples, respectively.

340 As seen in Fig. 1, the first step was to measure the depth penetration of consolidants in the cross-sections of the limestone slabs. Fig.3 shows the real depth penetration of the treatments

342 via the yellow fluorescence of the $\mathrm{ZnO}$ QDs. In the case of the $\mathrm{Ca}(\mathrm{OH})_{2} / \mathrm{ZnO} @$ APTES 
nanoparticles, the depth penetration was $1 \mathrm{~cm}$ (thickness of the slabs), while in

$344 \mathrm{Ca}(\mathrm{OH})_{2} / \mathrm{ZnO} @$ TEOS nanocomposites, it was slightly less at $0.85 \mathrm{~cm}$.

345 The chemical analyses made by EDS evidenced the presence of $\mathrm{Zn}$ (ZnO QDs) along the cross-

346 sectioned slabs (Fig. 4) for both nanoparticles. Moreover, the suitability of this UV method for

347 the detection of the real penetration of nanoparticles was confirmed by detecting $\mathrm{Zn}$ in the

348 consolidated areas.

349 In the samples treated with the $\mathrm{Ca}(\mathrm{OH})_{2} / \mathrm{ZnO} @$ TEOS nanocomposites (Fig. 4 A), there

350 appeared some calcite crystals, although some amorphous phases were appreciable, thus

351 drawing out the carbonatation process and, consequently, decreasing the consolidation

352 properties. The sample with $\mathrm{Ca}(\mathrm{OH})_{2} / \mathrm{ZnO} @$ APTES nanoparticles (Fig. $4 \mathrm{~B}$ ) indicates the

353 finalization of the carbonatation process with the formation of rhombohedral crystal structures

354 of calcite, which is in agreement with Rodriguez-Navarro [31].

355 The carbonatation process shows remarkable differences between the two silica-coated 356 nanoparticle treatments. For this reason, $\mathrm{Ca}(\mathrm{OH})_{2} / \mathrm{ZnO} @$ APTES nanoparticles were chosen to 357 treat the stones in the following steps of this work.
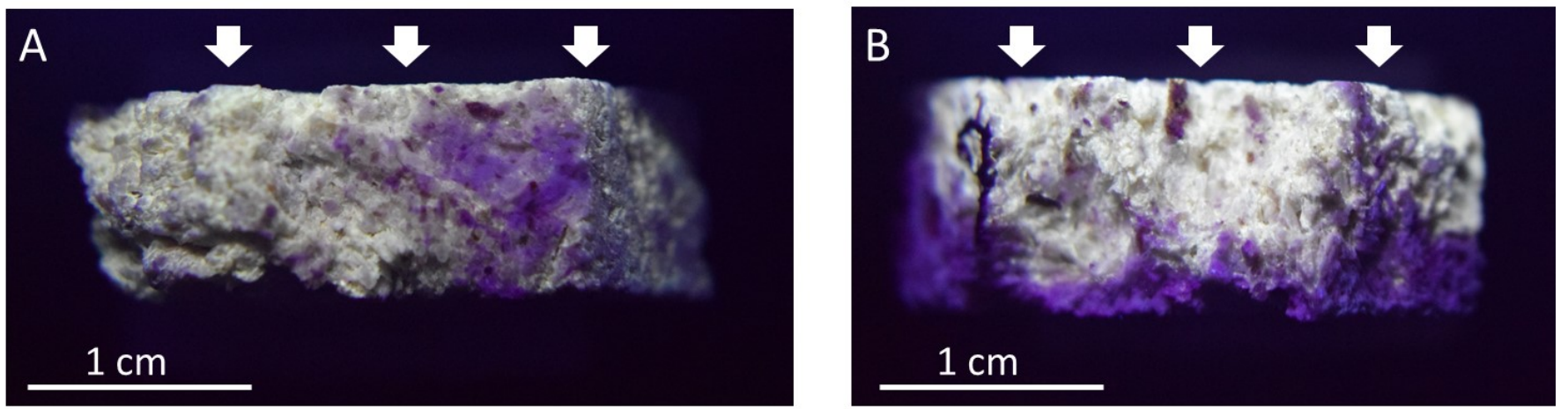

359 Fig. 3. Cross-section of limestones treated with $\mathrm{Ca}(\mathrm{OH})_{2} / \mathrm{ZnO} @$ APTES (A) and $360 \mathrm{Ca}(\mathrm{OH})_{2} / \mathrm{ZnO} @ \operatorname{TEOS}(\mathrm{B})$ under UV radiation $(254 \mathrm{~nm})$. 

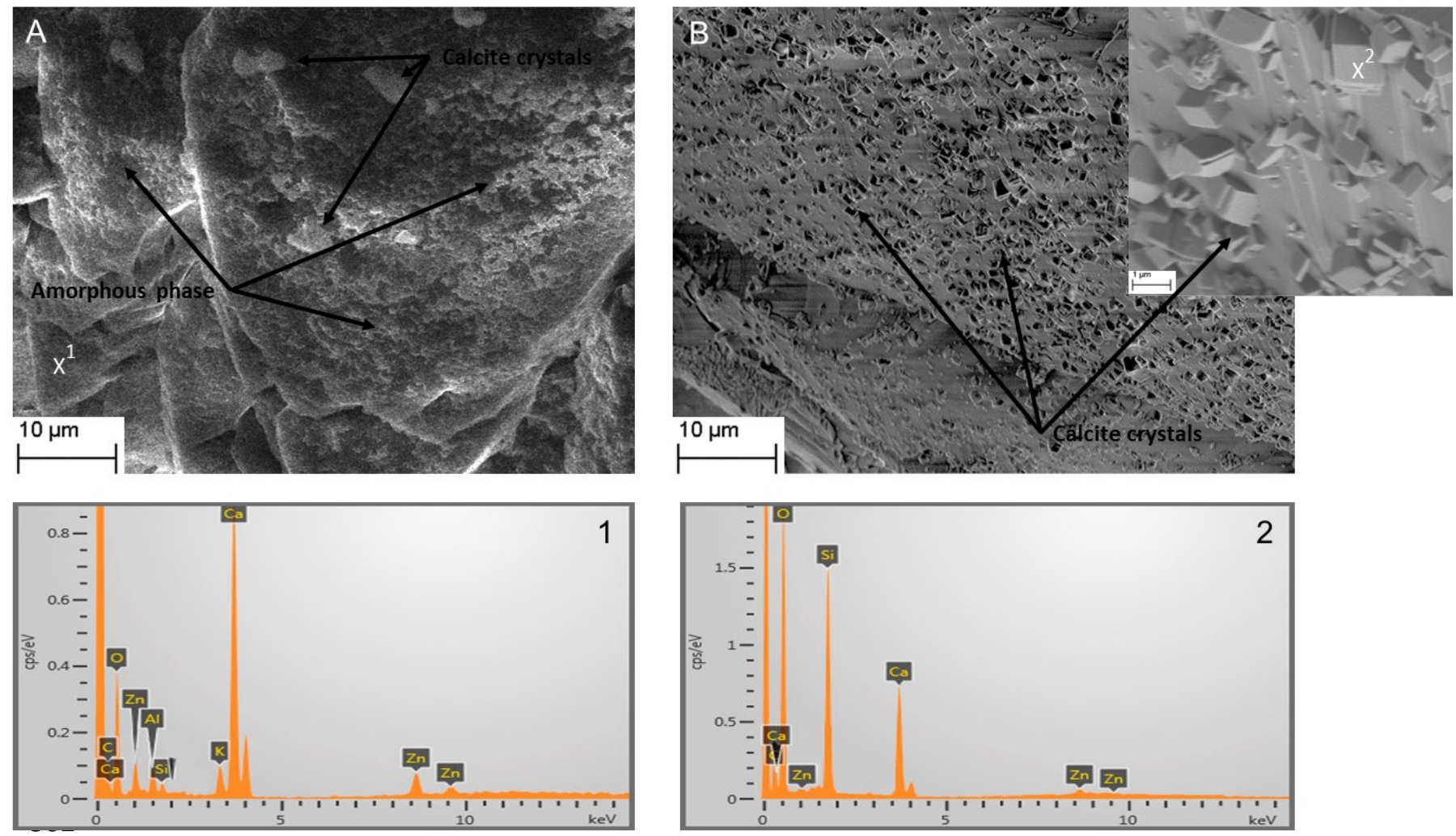

363

Fig 4. The SEM images of the treatments applied over PMS limestone after 20 days of drying.

364

(A) $\mathrm{Ca}(\mathrm{OH})_{2} / \mathrm{ZnO} @$ TEOS nanoparticles. Point 1 corresponds to the EDS analysis.

(B)

$365 \mathrm{Ca}(\mathrm{OH})_{2} / \mathrm{ZnO} @$ APTES nanoparticles. Point 2 corresponds to the EDS analysis.

\subsubsection{Application on stone samples and evaluation of treatments}

The evaluation of the treatments was carried out by applying $\mathrm{Ca}(\mathrm{OH})_{2} / \mathrm{ZnO} @$ APTES nanolimes (Nanorestore $\AA)$.

Aesthetical characteristics based on colour change must be analysed for the treatment evaluation applied on cultural heritage sites. Although there are not clear standardized criteria for colour changes, the most common criterion is that the treatment cannot change the colour by $\Delta \mathrm{E}^{*}>5$ [48-50]. Other authors propose three ranges of chromatic changes for dyes in cultural heritage porous materials: $\Delta \mathrm{E}^{*}<5$, which is where chromatic changes cannot be detected by the human eye; $5<\Delta \mathrm{E}^{*}<10$, which is where chromatic changes can be detected by the human eye but are still acceptable; and $\Delta \mathrm{E}^{*}>10$, which is where chromatic changes are clearly visible [51-53]. 
377 Consequently, we classify optimal treatments as those with $\Delta \mathrm{E}^{*}<5$ and acceptable treatments as

378 those with $5<\Delta \mathrm{E}^{*}<10$.

379 In the case of the treatments applied over PSM limestone, the values of $\Delta \mathrm{E}^{*}$ generally were 380 lower than 5 (Table 4) and consequently optimal for cultural heritage; the exceptions were the 381 applications in water or dipentene, where the high standard deviations showed the 382 heterogeneous behaviours of the treatments, and the $\Delta \mathrm{E}^{*} \mathrm{~s}$ were 5.5 and 6 , respectively. None of 383 the colour increments exceeded the value of 10 , and so all treatments were acceptable. The least 384 pronounced colour changes were achieved by alcohol dispersions (approximately 2), without remarkable differences between treatments. These good results are due to the high porosity of this limestone $(14.3 \%)$ and its large pore size $(10-100 \mu \mathrm{m})$, which allowed a better depth penetration of the treatments. No white haze was observed in the treated samples, as seen in the example of the application in ethanol (Fig. 5A-C). Any remarkable difference could be appreciated between the $\Delta \mathrm{E}^{*}$ caused by the $\mathrm{Ca}(\mathrm{OH})_{2} / \mathrm{ZnO} @$ APTES and $\mathrm{Ca}(\mathrm{OH})_{2}$ nanoparticles (Table 4).

In the ESP limestone, the $\Delta \mathrm{E}^{*}$ values were higher, thus exceeding the value of 10 in several occasions. This result was due to the physical properties of the stone, with a lower porosity $(5.9 \%)$ and lower range of porous size $(10-75 \mu \mathrm{m})$. The accumulation of the treatment on the surface produced a white haze, which is responsible for the higher colour changes. Fig. 5D-F show the white haze generated after the application of the treatments suspended in ethanol. The presence of $\mathrm{ZnO}$ QDs increased the white haze over the stone, which was amplified by the increment of $\mathrm{L}^{*}$ (brightness) and, consequently, the increased $\Delta \mathrm{E}^{*}$ over 5 . The treatment is not the most advisable on surfaces that must be visible, although it would be acceptable on hidden stone surfaces. 


\begin{tabular}{|c|c|c|c|c|c|c|c|c|c|c|}
\hline \multirow[b]{3}{*}{ Solvent } & \multicolumn{5}{|c|}{ Puerto de Santa María (PSM) } & \multicolumn{5}{|c|}{ Espera (ESP) } \\
\hline & \multicolumn{2}{|c|}{$\mathrm{Ca}(\mathrm{OH})_{2}$} & \multicolumn{3}{|c|}{$\mathrm{Ca}(\mathrm{OH})_{2} / \mathrm{ZnO} @$ APTES } & \multicolumn{2}{|c|}{$\mathrm{Ca}(\mathrm{OH})_{2}$} & \multicolumn{3}{|c|}{$\mathrm{Ca}(\mathrm{OH})_{2} / \mathrm{ZnO} @ \mathrm{APTES}$} \\
\hline & $\Delta \mathbf{E}^{*}$ & \begin{tabular}{|c|}
$\%$ \\
Consoli- \\
dation $^{+}$
\end{tabular} & $\Delta \mathbf{E}^{*}$ & $\begin{array}{c}\% \\
\text { Consoli- } \\
\text { dation }^{+}\end{array}$ & $\begin{array}{c}\text { Depth }^{++} \\
(\mathrm{mm})\end{array}$ & $\Delta \mathbf{E}^{*}$ & \begin{tabular}{|c|}
$\%$ \\
Consoli- \\
dation $^{+}$
\end{tabular} & $\Delta \mathbf{E}^{*}$ & \begin{tabular}{|c|}
$\%$ \\
Consoli- \\
dation $^{+}$
\end{tabular} & $\begin{array}{c}\text { Depth }^{++} \\
\text {(mm) }\end{array}$ \\
\hline Water & $5.43 \pm 2.3$ & 89.07 & $5.45 \pm 3.3$ & 82.52 & $1.39 \pm 0.4$ & $6.97 \pm 3.1$ & 24.09 & $8.34 \pm 2.2$ & 45.77 & $0.27 \pm 0.17$ \\
\hline Ethanol & $1.79 \pm 1.4$ & 61.30 & $2.04 \pm 1.3$ & 92.29 & $11.16 \pm 1.4$ & $6.21 \pm 2.3$ & 50.72 & $10.60 \pm 1.3$ & 31.18 & $0.09 \pm 0.03$ \\
\hline Isopropanol & $2.29 \pm 1.9$ & 71.40 & $1.98 \pm 0.2$ & 94.96 & $9.65 \pm 0.1$ & $7.48 \pm 1.9$ & 41.85 & $11.66 \pm 4.4$ & 30.60 & $0.28 \pm 0.22$ \\
\hline Acetone & $4.53 \pm 0.9$ & 53.49 & $3.70 \pm 0.8$ & 93.74 & $4.37 \pm 2.0$ & $7.57 \pm 1.1$ & 17.64 & $11.78 \pm 10.2$ & 24.60 & $0.21 \pm 0.09$ \\
\hline Dipentene & $6.38 \pm 5.5$ & 59.75 & $5.73 \pm 5.2$ & 94.12 & $1.68 \pm 0.8$ & $8.45 \pm 1.3$ & 59.43 & $19.01 \pm 4.5$ & 17.64 & $0.18 \pm 0.16$ \\
\hline
\end{tabular}

$\%$ of the grade of consolidation with respect to the untreated samples. Equation (Eq. 3) in section 2.6.
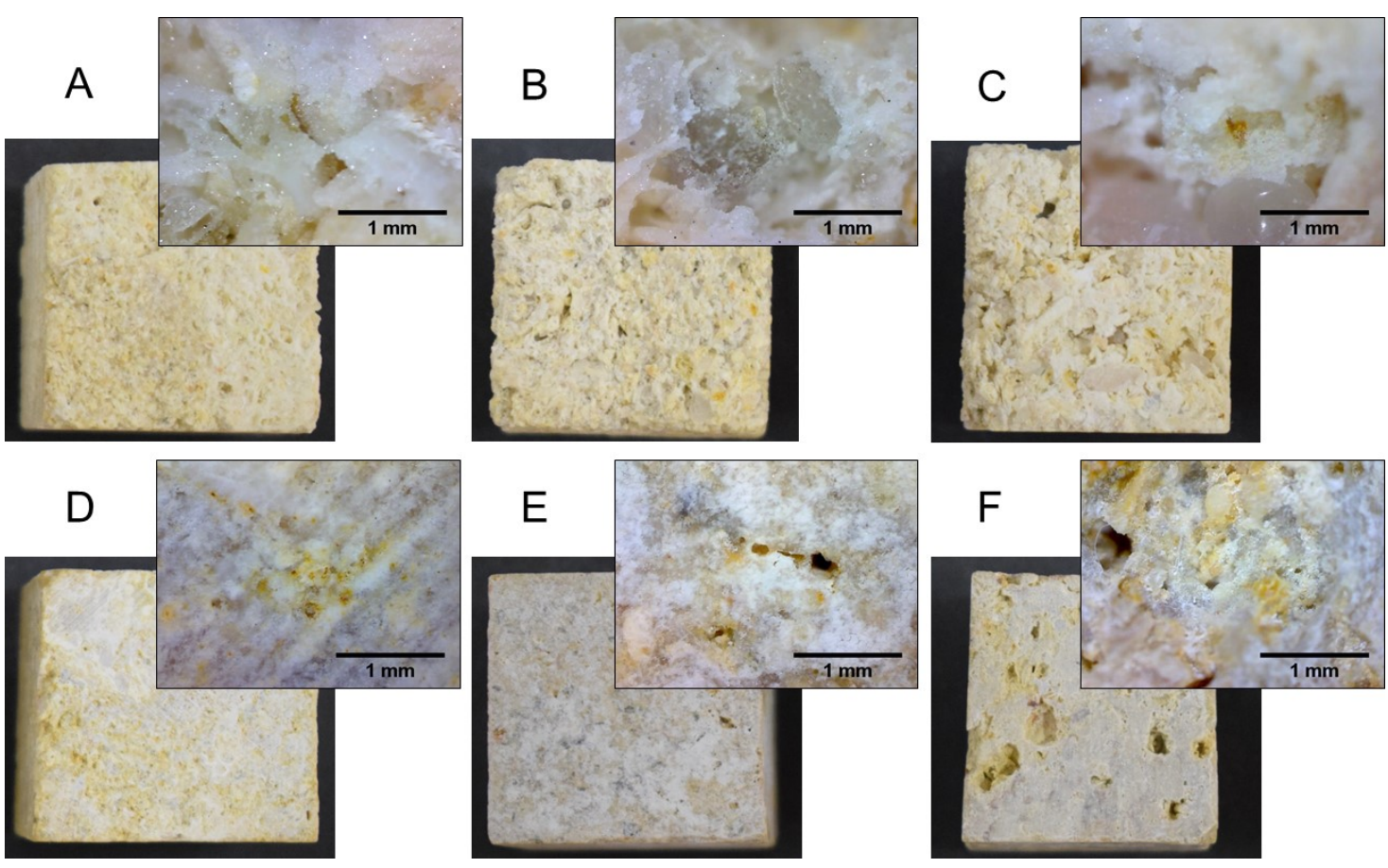

Fig. 5. Photography of limestone surfaces after the application of the different treatments with ethanol. Magnification of the surface $(140 \mathrm{x})$ analysed by a Zarbeco handheld digital microscope. (A) Untreated PSM limestone. (B) $\mathrm{Ca}(\mathrm{OH})_{2} / \mathrm{ZnO} @$ APTES applied over PSM limestone. (C) $\mathrm{Ca}(\mathrm{OH})_{2}$ applied over PSM limestone. (D) Untreated ESP limestone. (E)

$410 \mathrm{Ca}(\mathrm{OH})_{2} / \mathrm{ZnO} @$ APTES applied over ESP limestone. $(\mathrm{F}) \mathrm{Ca}(\mathrm{OH})_{2}$ applied over ESP limestone.

411 The colour changes are related to the treatment penetration, and we observed that the lowest $412 \Delta \mathrm{E}^{*}$ was favoured by a good depth penetration of the treatments. The penetration depends on 
texture of the stone and the solvent that is employed. The cross-section of the samples treated with the $\mathrm{Ca}(\mathrm{OH})_{2} / \mathrm{ZnO} @$ APTES nanocomposites allows us to measure the real depth of the treatment under UV radiation $(\lambda=254 \mathrm{~nm})$. The suitability of the UV method for the detection of real penetration was confirmed in the preliminary trial by EDS, which detected $\mathrm{Zn}$ only in the consolidated areas. The penetration capability of the treatments is widely connected with the texture and porosity of the limestone and the solvent chosen. In this sense, the treatments that generated a homogeneous white layer over the surface of the ESP limestone had low penetration, as was evidenced by the UV light in the cross-section (Fig. 6F-I) in which the penetration thickness was a few micrometres (Table 4), and the values were closely related to the roughness of the stone, as can be deduced by the greater deviations of the penetration measurements. The superficial deposition of the treatments agrees with the highest $\Delta \mathrm{E}^{*}$ observed (higher than 10). On the other hand, the treatments had a noticeable penetration in PSM limestone according to the UV measurements (Fig 6B-D), thus achieving a depth penetration greater than $1 \mathrm{~cm}$ in alcohol dispersions, with the lowest colour increments $(<2.3)$. The other solvents had depth penetration according to their colour increments, while water and dipentene had the worst depth penetration, approximately $1.5 \mathrm{~mm}$. In conclusion, a good selection of the solvent allows one to improve the penetration of nanoparticles by more than 1 $\mathrm{cm}$.

Table 4 shows the measurements of the depth penetration achieved by the different dispersions. The low surface tension of the alcohols $\left(21 \mathrm{mN} \mathrm{m}^{-1}\right)$ and their good kinetic stability $(>48 \mathrm{~h})$ favoured a great penetration depth, especially in the case of ethanol, which reached a penetration of over $1.1 \mathrm{~cm}$ in PSM stone. This depth is even greater than those reached by other authors for nanolimes without QDs $[7,9,44]$. The water and dipentene solvents displayed the lowest penetration depths, although these solvents present a higher superficial tension (71.97 $\mathrm{mN} \mathrm{m}^{-1}$ and $26.87 \mathrm{mN} \mathrm{m}^{-1}$, respectively) and a lower viscosity $(0.89 \mathrm{mPas}$ and $0.92 \mathrm{mPas}$, respectively), which are characteristics that were exposed by Borsoy et al. [8] as critical to achieving a good penetration of a treatment by capillarity. In this case, the application methods 
441 achieving greater results when the solvent has a low superficial tension, which is in agreement 442 with Chelizzia et al. [11].
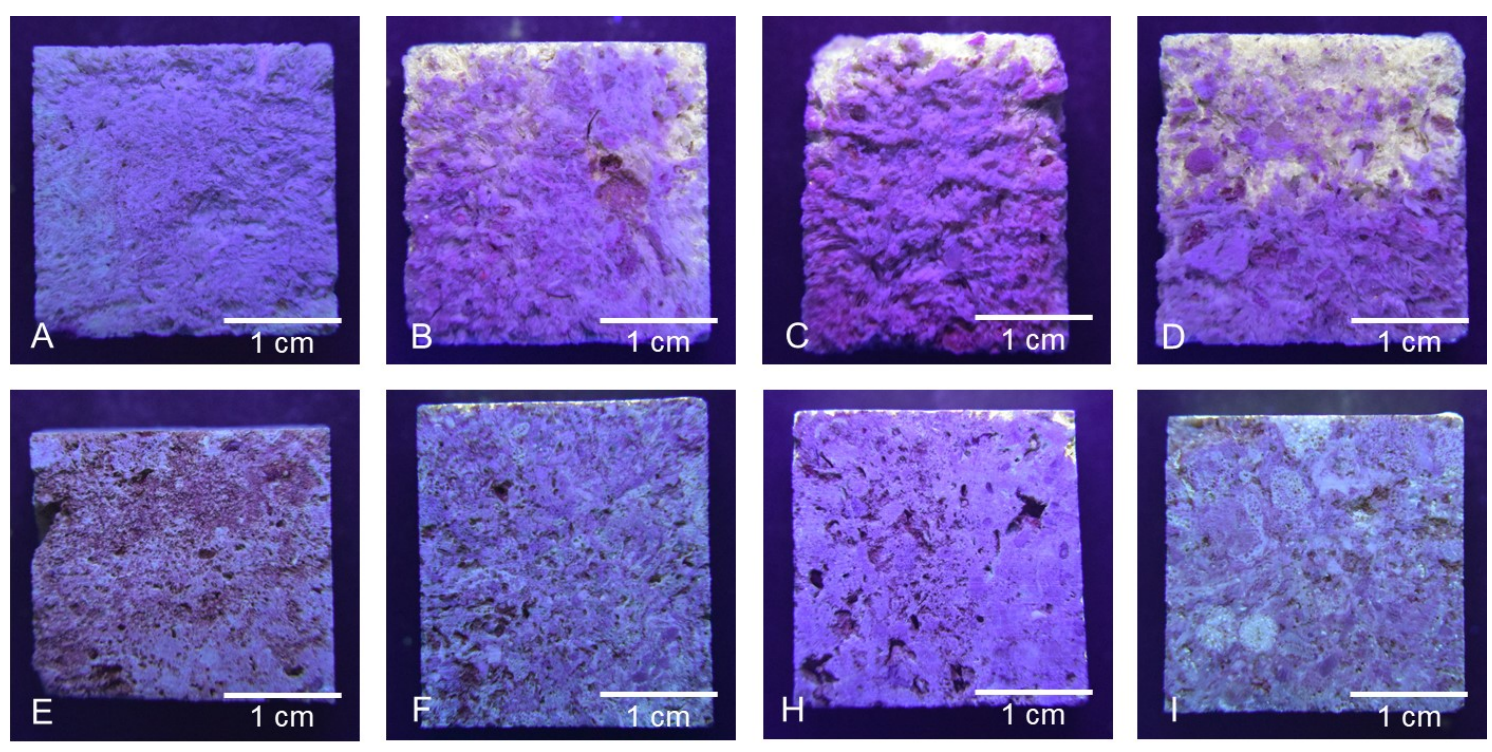

Fig. 6. Photography under UV radiation $(254 \mathrm{~nm})$ of the cross section of the samples treated with the $\mathrm{Ca}(\mathrm{OH})_{2} / \mathrm{ZnO} @$ APTES nanocomposites that were suspended in different solvents. The first row corresponds to the PMS limestone and the second one to the ESP limestone. (A) Untreated. (B) Dipentene. (C) Acetone. (D) Ethanol. (E) Untreated. (F) Dipentene. (H) Acetone. (I) Ethanol.

Phenolphthalein tests were carried out over the cross-sectioned stones after 20 days of drying. The absence of the typical purple colour change by the reaction of the phenolphthalein at $\mathrm{pH}>9.8$ established the total conversion of the nanolimes in calcite at $\mathrm{pH}$ values lower than 8.2.

The peeling test results indicated that the treatments increased the superficial cohesion of the treated limestones. The percentage of consolidation depended on the limestone (Table 4). in $50 \%$ of the cases of nanolimes applied in dipentene and ethanol. In the case of the $\mathrm{Ca}(\mathrm{OH})_{2} / \mathrm{ZnO} @$ APTES nanoparticles, the consolidation that was achieved was less, with the best results with water (46\%). The rest of the solvents did not have remarkable consolidation in 
this limestone, with some results lower than 30\%, except for the nanolimes applied on

459 isopropanol.

460 In contrast, the consolidation achieved in the PSM limestone was very noticeable. All the

461 treatments reduced the powdering of this limestone by more than $50 \%$, and this percentage was

462 increased to more than 80 in the case of $\mathrm{Ca}(\mathrm{OH})_{2} / \mathrm{ZnO} @$ APTES. In this sense,

$463 \mathrm{Ca}(\mathrm{OH})_{2} / \mathrm{ZnO} @$ APTES showed better results than those of the nanolimes alone. The best result

464 was obtained with isopropanol (95\% of consolidation).

465 Figure 7 shows the evolution of different repetitions of the peeling assay. The typical trend is a

466 reduction in the amount of removed material in successive repetitions, which consequently

467 shows a decreasing linear progression. The gradient of this linear progression was more

468 pronounced in the decayed stones, such as the untreated PSM limestone in Fig. 7A. A good

469 consolidation of the stone decreases the removed material, and the gradient of the linear

470 progression tends to be a horizontal line. Those lines near the horizontal imply a homogeneous

471 state of conservation of the stone surface.

472 In the case of PSM limestone, the greater consolidation was obtained by

$473 \mathrm{Ca}(\mathrm{OH})_{2} / \mathrm{ZnO} @$ APTES nanoparticles applied in the isopropanol dissolution, thus showing a

474 horizontal progression line in Fig. 7A (dotted lines). This good result with respect to

475 commercial $\mathrm{Ca}(\mathrm{OH})_{2}$ nanoparticles is due to the slight presence of APTES, which increased the

476 consolidation property of the treatment and avoided the formation of typical microcracks that

477 are reported in some studies of the application of ethyl silicates on limestones [18]. In this

478 sense, the lack of APTES in the consolidation treatment lowered the effectiveness of the

479 treatment by $30 \%$. In the case of the ESP limestone, the progression lines of the treatments are

480 similar to the untreated sample and display a lower capability to consolidate the material, which

481 may be due to this limestone having less damage by powdering. 


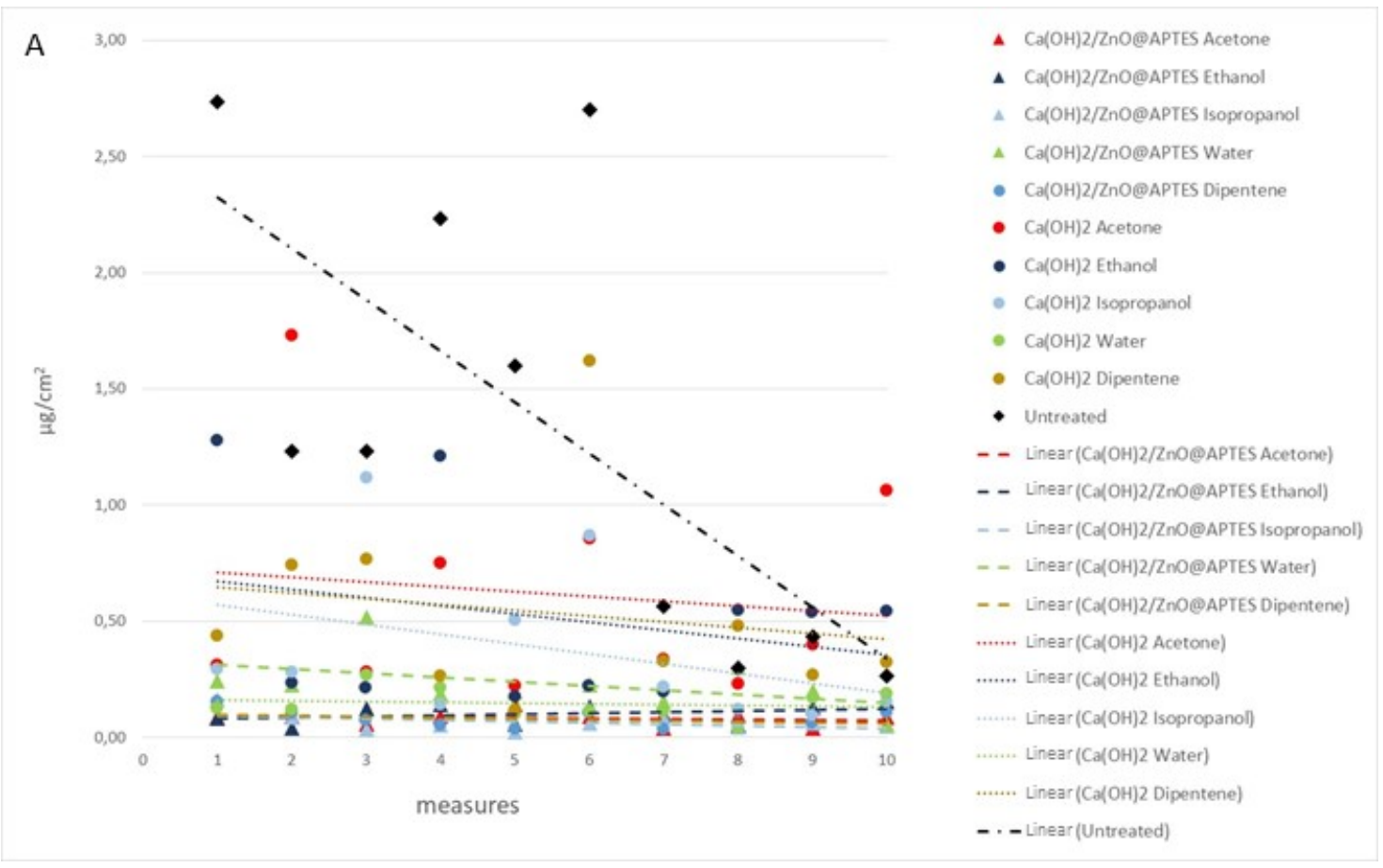

Fig. 7. Average of the peeling tests on Puerto de Santa María (A) and Espera (B) limestone after the consolidation treatment and lineal progression lines. 
489

490

491

492

493

494

495

496

497

498

499

500

501

502

503

504

505

506

507

508

509

510

511

512

513

Treatments based on nanolimes were evaluated as consolidants of limestones. One of the problems of this treatment is achieving a good depth penetration and avoiding the formation of white haze in the stone surfaces. For those purposes, the kinetic stability of dispersion with different solvents and the nanoparticle affinity for the solvents and the substrates were studied. The highest kinetic stabilities were obtained with alcohol solvents that, in general, had the highest distance travelled by the nanoparticles relative to the solvent in the chromatography assays.

Moreover, two different silica products were tested as stabilizers in the synthesis of the $\mathrm{ZnO}$ QDs, TEOS and APTES. The influence of the silica coatings in the consolidation properties of the nanolimes was researched. Although apparently both silica coatings had similar behaviours, the SEM images showed that the presence of TEOS favoured the formation of amorphous $\mathrm{CaCO}_{3}$, while in the samples with $\mathrm{Ca}(\mathrm{OH})_{2} / \mathrm{ZnO} @$ APTES nanoparticles, the SEM showed calcite crystals.

The trials in two different limestones allowed us to establish a third condition to take into consideration, the physical characteristics of the stone; this aspect was especially related to the porosity and pore size range of the stone. Based on the results of this study, to achieve a good penetration, the stone porosity should be greater than $14 \%$ with a predominantly high porous size. These characteristics allowed us to obtain good consolidation, as demonstrated by the decrease in colour changes, thus avoiding the formation of white haze on the stone surfaces.

The capability to measure the depth penetration of the treatment by the fluorescence of $\mathrm{ZnO}$ QDs was confirmed. The ZnO QDs remained on the nanolime surfaces without increasing in average size and showed a great fluorescence in the visible region under UV irradiation. These stable, nontoxic and low-cost QDs allowed us to conclude that the selection of the solvent is decisive in achieving a high depth penetration. As it was evaluated, the chosen solvents improved the depth penetration from a few millimetres (water) to more than 1 centimetre 
514 (ethanol). This difference is related to the low superficial tension of the solvents and the high

515 kinetic stability of the dispersions when they are applied by brushing.

516 Finally, the consolidation effectiveness of nanolimes were improved with

$517 \mathrm{Ca}(\mathrm{OH})_{2} / \mathrm{ZnO} @$ APTES nanoparticles. The consolidation achieved in high porous limestone 518 was greater than $90 \%$. This treatment is a benefit for on-site works of restoration in cultural 519 heritage sites since the treatment can be controlled via UV radiation. Therefore, this method is 520 an easy, environmentally friendly and economical approach to establish a perceptible 521 consolidation treatment.

\section{Acknowledgements}

523 This study has been partially supported by the projects: BIA2015-64878-R (Art-Risk, RETOS 524 project of Ministerio de Economía y Competitividad and Fondo Europeo de Desarrollo 525 Regional), CTQ2013-48396-P (Ministerio de Economía y Competitividad and Fondo Europeo 526 de Desarrollo Regional) and the research teams TEP-199, P10-FQM-6615 and FQM-319 from 527 Junta Andalucía. J. Becerra is grateful to the Ministerio de Educación, Cultura y Deporte for his 528 pre-doctoral fellowship (FPU14/05348) and to the University Ecclesiastical Academy of 529 Thessaloniki for his stay as visiting researcher.

\section{References}

531 [1] G. B, R.H. Van, B. L, R. V, A.S. S, Nanolime deposition in Maastricht limestone : back-

[2] R. van Hees, R. Veiga, Z. Slížková, Consolidation of renders and plasters, Mater. Struct. 50 (2017) 65. doi:10.1617/s11527-016-0894-5.

537 [3] M. Favaro, R. Mendichi, F. Ossola, U. Russo, S. Simon, P. Tomasin, P.A. Vigato, Evaluation of polymers for conservation treatments of outdoor exposed stone 
monuments. Part I: Photo-oxidative weathering, Polym. Degrad. Stab. 91 (2006) 30833096. doi:10.1016/j.polymdegradstab.2006.08.012.

541 [4] S. Vicini, S. Margutti, G. Moggi, E. Pedemonte, In situ copolymerisation of ethylmethacrylate and methylacrylate for the restoration of stone artefacts, J. Cult. Herit. 2 (2001) 143-147. doi:10.1016/S1296-2074(01)01114-1.

[6] P. Baglioni, D. Chelazzi, R. Giorgi, E. Carretti, N. Toccafondi, Y. Jaidar, Commercial $\mathrm{Ca}(\mathrm{OH}) 2$ nanoparticles for the consolidation of immovable works of art, Appl. Phys. A

[9] V. Daniele, G. Taglieri, R. Quaresima, The nanolimes in Cultural Heritage conservation: Characterisation and analysis of the carbonatation process, J. Cult. Herit. 9 (2008) 294301. doi:10.1016/j.culher.2007.10.007.

[10] R. Giorgi, M. Ambrosi, N. Toccafondi, P. Baglioni, Nanoparticles for cultural heritage conservation: Calcium and barium hydroxide nanoparticles for wall painting consolidation, Chem. - A Eur. J. 16 (2010) 9374-9382. doi:10.1002/chem.201001443.

D. Chelazzi, G. Poggi, Y. Jaidar, N. Toccafondi, R. Giorgi, P. Baglioni, Hydroxide nanoparticles for cultural heritage: Consolidation and protection of wall paintings and 
carbonate materials, J. Colloid Interface Sci. 392 (2013) 42-49. doi:10.1016/j.jcis.2012.09.069.

[12] R. Giorgi, L. Dei, P. Baglioni, A New Method for Consolidating Wall Paintings Based on Dispersions of Lime in Alcohol, Stud. Conserv. 45 (2000) 154-161. doi:10.1179/sic.2000.45.3.154.

[13] I. Natali, M.L. Saladino, F. Andriulo, D. Chillura Martino, E. Caponetti, E. Carretti, L. Dei, Consolidation and protection by nanolime: Recent advances for the conservation of the graffiti, Carceri dello Steri Palermo and of the 18th century lunettes, SS. Giuda e Simone Cloister, Corniola (Empoli), J. Cult. Herit. 15 (2014) 151-158. doi:10.1016/j.culher.2013.03.002.

[14] G. Taglieri, V. Daniele, G. Rosatelli, S. Sfarra, M.C. Mascolo, C. Mondelli, Ecocompatible protective treatments on an Italian historic mortar (XIV century), J. Cult. Herit. 25 (2017) 135-141. doi:10.1016/J.CULHER.2016.12.008.

[15] C. Rodriguez-Navarro, A. Suzuki, E. Ruiz-Agudo, Alcohol Dispersions of Calcium Hydroxide Nanoparticles for Stone Conservation, Langmuir. 29 (2013) 11457-11470. doi:10.1021/la4017728.

[16] D. Costa, J.D. Rodrigues, Consolidation of a porous limestone with nanolime, 12th Int. Congr. Deterior. Conserv. Stone. (2013).

[17] G. Taglieri, J. Otero, V. Daniele, G. Gioia, L. Macera, V. Starinieri, A.E. Charola, The biocalcarenite stone of Agrigento (Italy): Preliminary investigations of compatible nanolime treatments, J. Cult. Herit. 30 (2018) 92-99. doi:10.1016/J.CULHER.2017.11.003.

[18] G. Borsoi, M. Tavares, R. Veiga, A.S. Silva, Microstructural Characterization of Consolidant Products for Historical Renders: An Innovative Nanostructured Lime Dispersion and a More Traditional Ethyl Silicate Limewater Solution, Microsc. 
590

591

592

593

594

595

596

597

598

599

600

601

602

603

604

605

606

607

608

609

610

611

612

613

[19] G. Borsoi, B. Lubelli, R. van Hees, R. Veiga, A. Santos Silva, Evaluation of the effectiveness and compatibility of nanolime consolidants with improved properties, Constr. Build. Mater. 142 (2017) 385-394. doi:10.1016/j.conbuildmat.2017.03.097.

[20] M.A. Guerrero, Diagnóstico del estado de alteración de la piedra del Palacio Consistorial de Sevilla. Causas y mecanismos, Universidad de Sevilla (Spain), 1990.

[21] M.Á. Bello López, Caracterización y estado de alteración química de los materiales empleados en la construción de la Catedral de Sevilla, Univerisdad de Sevilla, 1988.

[22] D. Millers, L. Grigorjeva, W. Łojkowski, T. Strachowski, Luminescence of ZnO nanopowders, Radiat. Meas. 38 (2004) 589-591. doi:10.1016/J.RADMEAS.2004.05.001.

[23] K. Matsuyama, Y. ki Maeda, T. Matsuda, T. Okuyama, H. Muto, Formation of poly(methyl methacrylate)-ZnO nanoparticle quantum dot composites by dispersion polymerization in supercritical CO2, J. Supercrit. Fluids. 103 (2015) 83-89. doi:10.1016/j.supflu.2015.04.025.

[24] Y. Zhang, T.R. Nayak, H. Hong, W. Cai, Biomedical applications of zinc oxide nanomaterials., Curr. Mol. Med. 13 (2013) 1633-45. http://www.ncbi.nlm.nih.gov/pubmed/24206130 (accessed July 15, 2018).

[25] M.K. Patra, M. Manoth, V.K. Singh, G. Siddaramana Gowd, V.S. Choudhry, S.R. Vadera, N. Kumar, Synthesis of stable dispersion of $\mathrm{ZnO}$ quantum dots in aqueous medium showing visible emission from bluish green to yellow, J. Lumin. 129 (2009) 320-324. doi:10.1016/j.jlumin.2008.10.014.

[26] G. Borsoi, B. Lubelli, R. van Hees, R. Veiga, A.S. Silva, Optimization of nanolime solvent for the consolidation of coarse porous limestone, Appl. Phys. A. 122 (2016) 846. doi:10.1007/s00339-016-0382-3. 
614 [27] A. Wypych, Databook of Solvents, ChemTec Publishing, Toronto, 2014.

615

616

617

618

619

620

621

622

623

624

625

626

627

628

629

630

631

632

633

634

635

636

637
[28] C. Reichardt, Empirical Parameters of Solvent Polarity as Linear Free-Energy Relationships, Angew. Chemie Int. Ed. English. 18 (1979) 98-110. doi:10.1002/anie.197900981.

[29] PubChem, The PubChem Project, (2017). https://pubchem.ncbi.nlm.nih.gov/ (accessed May 21, 2018).

[30] L. Masschelein-Kleiner, Los solventes (The Solvents), Centro Nacional de Conservación y Restauración DIBAM, Santiago de Chile, 2004.

[31] C. Rodriguez-Navarro, K. Elert, R. Ševčík, Amorphous and crystalline calcium carbonate phases during carbonation of nanolimes: Implications in heritage conservation, CrystEngComm. 18 (2016) 6594-6607. doi:10.1039/c6ce01202g.

[32] British Standards Institution., Natural stone test methods : determination of water absorption at atmospheric pressure., British Standards Institution, 2008.

[33] AENOR, UNE-EN 1925, Natural Stone test methods. Determination of water absorption coefficient by capillarity, (1999).

[34] L. Pinho, M.J. Mosquera, Photocatalytic activity of TiO2-SiO2 nanocomposites applied to buildings: Influence of particle size and loading, Appl. Catal. B Environ. 134-135 (2013) 205-221. doi:10.1016/j.apcatb.2013.01.021.

[35] G. Borsoi, B. Lubelli, R. van Hees, R. Veiga, A. Santos Silva, Application Protocol for the Consolidation of Calcareous Substrates by the Use of Nanolimes: From Laboratory Research to Practice, Restor. Build. Monum. 0 (2017). doi:10.1515/rbm-2016-0008.

[36] M. Drdácký, J. Lesák, S. Rescic, Z. Slížková, P. Tiano, J. Valach, Standardization of peeling tests for assessing the cohesion and consolidation characteristics of historic stone surfaces, Mater. Struct. 45 (2012) 505-520. doi:10.1617/s11527-011-9778-x. 
[37] B. Salvadori, L. Dei, Synthesis of $\mathrm{Ca}(\mathrm{OH}) 2$ nanoparticles from diols, Langmuir. 17 (2001) 2371-2374. doi:10.1021/1a0015967.

[38] L.S. Gomez-Villalba, P. López-Arce, A. Zornoza, M. Álvarez de Buergo, R. Fort, Evaluación del tratamiento de consolidación de dolomías mediante nanopartículas de hidróxido de calcio en condiciones de alta humedad relativa, Bol. La Soc. Esp. Ceram. y Vidr. 50 (2011) 85-92. doi:10.3989/cyv.122011.

[39] A.M. Pourrahimi, D. Liu, V. Ström, M.S. Hedenqvist, R.T. Olsson, U.W. Gedde, Heat treatment of $\mathrm{ZnO}$ nanoparticles: new methods to achieve high-purity nanoparticles for high-voltage applications, J. Mater. Chem. A. 3 (2015) 17190-17200. doi:10.1039/c5ta03120f.

[40] E. Fratini, M.G. Page, R. Giorgi, H. Cölfen, P. Baglioni, B. Demé, T. Zemb, Competitive surface adsorption of solvent molecules and compactness of agglomeration in calcium hydroxide nanoparticles, Langmuir. 23 (2007) 2330-2338. doi:10.1021/la062023i.

[41] N. Chekina, D. Horák, P. Jendelová, M. Trchová, M.J. Beneš, M. Hrubý, V. Herynek, K. Turnovcová, E. Syková, Fluorescent magnetic nanoparticles for biomedical applications, J. Mater. Chem. 21 (2011) 7630. doi:10.1039/c1jm10621j.

[42] M. Ambrosi, L. Dei, R. Giorgi, C. Neto, P. Baglioni, Stable dispersions of $\mathrm{Ca}(\mathrm{OH}) 2$ in aliphatic alcohols : properties and application in cultural heritage conservation, Prog. Colloid Polym. Sci. 118 (2001) 68-72. doi:10.1007/3-540-45725-9_15.

[43] C. Rodriguez-Navarro, I. Vettori, E. Ruiz-Agudo, Kinetics and Mechanism of Calcium Hydroxide Conversion into Calcium Alkoxides: Implications in Heritage Conservation Using Nanolimes, Langmuir. 32 (2016) 5183-5194. doi:10.1021/acs.langmuir.6b01065.

[44] M. Licchelli, M. Malagodi, M. Weththimuni, C. Zanchi, Nanoparticles for conservation of bio-calcarenite stone, Appl. Phys. A Mater. Sci. Process. 114 (2014) 673-683. 
664

665

666

667

668

669

670

671

672

673

674

675

676

677

678

679

680

681

682

683

684

685

686

687

[45] C. Rodriguez-Navarro, E. Ruiz-Agudo, M. Ortega-Huertas, E. Hansen, Nanostructure and irreversible colloidal behavior of $\mathrm{Ca}(\mathrm{OH}) 2$ : Implications in cultural heritage conservation, Langmuir. 21 (2005) 10948-10957. doi:10.1021/la051338f.

[46] G. Poggi, N. Toccafondi, D. Chelazzi, P. Canton, R. Giorgi, P. Baglioni, Calcium hydroxide nanoparticles from solvothermal reaction for the deacidification of degraded waterlogged wood, J. Colloid Interface Sci. 473 (2016) 1-8. doi:10.1016/j.jcis.2016.03.038.

[47] R. Snethlage, Stone Conservation, in: S. Siegesmund, R. Snethlage (Eds.), Stone Archit., 5th ed., Springer Berlin Heidelberg, Berlin, Heidelberg, 2014: pp. 415-550. doi:10.1007/978-3-642-45155-3.

[48] L. Pinho, M. Rojas, M.J. Mosquera, Ag-SiO2-TiO2 nanocomposite coatings with enhanced photoactivity for self-cleaning application on building materials, Appl. Catal. B Environ. 178 (2015) 144-154. doi:10.1016/j.apcatb.2014.10.002.

[49] P. Sanmartín, F. Villa, A. Polo, B. Silva, B. Prieto, F. Cappitelli, Rapid evaluation of three biocide treatments against the cyanobacterium Nostoc sp. PCC 9104 by color changes, Ann. Microbiol. 65 (2015) 1153-1158. doi:10.1007/s13213-014-0882-3.

[50] L. Graziani, E. Quagliarini, M. D'Orazio, The role of roughness and porosity on the selfcleaning and anti-biofouling efficiency of $\mathrm{TiO} 2-\mathrm{Cu}$ and $\mathrm{TiO} 2-\mathrm{Ag}$ nanocoatings applied on fired bricks, Constr. Build. Mater. 129 (2016) 116-124. doi:10.1016/j.conbuildmat.2016.10.111.

[51] O. García, K. Malaga, Definition of the procedure to determine the suitability and durability of an anti-graffiti product for application on cultural heritage porous materials, J. Cult. Herit. 13 (2012) 77-82. doi:10.1016/j.culher.2011.07.004.

[52] P. Ortiz, V. Antúnez, R. Ortiz, J.M.M. Martín, M.A.A. Gómez, A.R.R. Hortal, B. 

surfaces, Appl. Surf. Sci. 283 (2013) 193-201. doi:10.1016/j.apsusc.2013.06.081.

690

[53] J. Becerra, A.P. Zaderenko, M.J. Sayagués, R. Ortiz, P. Ortiz, Synergy achieved in silver-TiO 2 nanocomposites for the inhibition of biofouling on limestone, Build. Environ. 141 (2018) 80-90. doi:10.1016/j.buildenv.2018.05.020.

693 